\title{
Cartographers, canons and cuckoos - historiography of the study of the Old Testament
}

H L Bosman

\section{ABSTRACT}

There is no obvious place for the historian of Old Testament studies amongst his exegetical and theological colleagues and little interest has been shown in this aspect of Old Testament studies. Some scholars view historians of science as intellectual cartographers of their discipline's unrelenting "progress" through the ages. Other scholars make use of the historiography of science to provide them with a personal canon of reputable predecessors in terms of which their own point of view ought to be understood. There are also those scholars who consider historians of science to be academic cuckoos who lay eggs in other birds' nests but who never produce anything "original" - they are considered to be mere compilers of the history of how the "real" academics got on with the job. The aim of this article is to relate recent trends in the historiography of science to some of the more important attempts at writing the history of the study of the Old Testament during the past 120 years ${ }^{1}$.

\section{HISTORY OF THE SCIENCES}

Although one might speculate about the possibility that Aristotle's Lyceum produced the first histories of the sciences (i e Theophrastus' lost History of Philosophy), it is definite that a keen interest in the origin and growth of science was first shown in the seventeenth century. The erudite William Wotton made it clear in his Reflections upon Ancient and Modern Learning (1694) that he considered the modern world superior to antiquity, due to the "growth" in science ${ }^{2}$. Attempts at writing a history of science during the eighteenth century paid more attention to the compilation of a chronicle of facts and figures than to historical or philosophical analysis. Göttingen became renowned for its flourishing school of universal history which led to the practice of tuition in each discipline being accompanied by lectures on its history 3 .

William Whewell wrote the first "modern" history of science in 1837 when his History of the inductive sciences was published. He saw scientific progress as a successful union of facts and ideas and he considered the tension between fact and idea to be the methodological point of departure for the understanding of the history of science 4 . During the middle of the nineteenth century positivistic historiography was intent upon the negation of any form of transcendency and the history of science thus became a vehicle for secular faith in the analytical and 
experimental methods in science 5 . Auguste Comte, like Whewell, supposed in his Course de philosophie positive (1830-42) that the best understanding of science is achieved only by a study of its history. History of science was first established as an academic discipline at the end of the nineteenth century when a chair was instituted at the College de France, due to positivist pressures.

The Austrian, Ernst Mach, considered scientific statements to be mere descriptions of natural phenomena and scientific theories to represent simplified summaries of scientific observations in the past. Although he acknowledged that certain theological concepts were responsible for the formulation of some scientific hypotheses, the theological points of view belonged to the scientist's "innermost life"6. Pierre Duhem subscribed to a certain extent to Mach's view that science merely systematised man's experience of natural phenomena. Yet he also maintained that the choice of hypotheses in science was determined by extra-scientific factors. Therefore Duhem conceived a history of science that focused on all the factors that influenced the formulation of scientific hypotheses 7 . His historiography of science showed gradualist and evolutionist tendencies because he presupposed a continuity in scientific thinking that did not allow for any intellectual "revolutions".

The rise of the Vienna Circle and logical positivism caused the philosophy of science to become ahistorical in character. History of science written in this period usually had positivistic assumptions and George Sarton therefore depicted the history of science as the history of man's "gradual unveiling of truth and the conquest of matter by mind"8. Thus the history of science became a narrative about the continuous, cumulative development of science.

Alexandre Koyré widened the horizons of the history of science with his "conceptual analysis", according to which science had to be studied as part of man's interrelated attitudes to nature and knowledge. He was convinced that the history of science could act as laboratory in which one could come to some understanding of the achievements of the human intellect in its search for truth ${ }^{9}$. Henry Guerlac praised Koyré's contribution, but also pointed out that not enough attention was paid to the political, social and technological dimensions of science. From his Marxist perspective he denounced the separation between scientific ideas and the "material reality" of social and economic experience ${ }^{10}$.

Karl Popper characterised Hegel and Marx as "historicist" because they made statements on patterns and trends in history which influenced human behaviour. He is convinced that historical determinism and historical inevitability are essential components of the "historicist" position. The process of problemsolving is considered to be typical of the evolutionary history of mankind and this process involves language, ethical systems, law, religion, philosophy and social institutions. Together they form the environment in which science evolves ${ }^{11}$.

Thomas Kuhn became widely known as an historian of science due to his 
book Structure of scientific revolutions, published in 1962, in which he distinguishes three periods in the histories of the different sciences. In the "pre-paradigm period" facts are gathered at random by divergent schools of thought without any generally accepted theoretical framework. As soon as one theoretical system receives general acceptance, the scientific discipline's first "paradigm" is established and a period of "normal science" is introduced. During the second period research is conducted according to the accepted paradigm, which had been provided by the previously successful research work carried out in the discipline. Eventually anomalous results occur and are dealt with by ad hoc hypotheses. The accumulation of ad hoc hypotheses causes the paradigm to fall into disrepute and the scientific discipline enters a "crisis". This third period, which Kuhn calls a "scientific revolution", is characterised by a questioning of a discipline's basic methodology and fundamental theoretical assumptions. Gradually a new paradigm is accepted and the scientific discipline settles down to a further period of "normal science" and "problem solving". In contrast to positivist or "whig" historiography which viewed science as a continuing process of the accumulation of knowledge, Kuhn identifies major discontinuities or "revolutions" in the history of science. Kuhn's view is distinguished by his utilisation of extra-scientific aspects to explain theoretical change in science and his work stimulated the Edinburgh sociologists of knowledge, Barnes and Bloor, to challenge the presuppositions of philosophically orientated history of science ${ }^{12}$.

At this stage it is possible to distinguish between a few trends in the historiography of science. The nineteenth and early twentieth century adhered to an inductivist or "whig" historiography of science which thought progressive discovery of naively realistic truth to be possible ${ }^{13}$. According to this "whiggish" approach, the discovery of scientific "facts" of necessity led to scientific theories because the facts spoke for themselves and theories emerged almost on their own from the facts ${ }^{14}$.

During the latter part of the twentieth century two basic approaches to the history of science evolved. On the one hand there is an idealistic, conventialist or "internal" history of science which understood past science in terms of its own internal criteria and its interrelationship with thought forms of its age. This approach assumes that certain canons or modes of rationality can be discerned in conceptual systems of the past and that it is possible to reconstruct past scientists' thoughts and arguments as being relatively autonomous from the context of the historiographer. The "internal" history concentrates on the history of scientific concepts and methods, often in the form of case-studies ${ }^{15}$. On the other hand we find the sociological or "external" historiography which explains science in terms of non-rational factors and which presupposes a social or broadly contextual conditioning of science. This trend focuses on the socio-historical context of science and investigates subjects like the influence of scientific institutions or the effect of professionalisation on academics. One should, however, keep in mind that the 
historiography of science during the past decade has moved away from the traditional somewhat rigid distinctions between "rational" or "irrational" and "internal" or "external"16.

Richard Rorty wrote an excellent article on the different genres of the historiography of philosophy in 1984 which has important implications for the history of science as a whole ${ }^{17}$. The first two genres concentrate on the reconstruction of the arguments of "great dead philosophers". This reconstruction can either be historical by giving an account of what "dead thinkers" meant in their own terms or it can be a rational reconstruction of a philosopher's significance according to the investigator's frame of reference. The third genre is referred to as a Geistesgeschichte and it combines historical and rational reconstruction to answer the basic question: Why should anyone have asked a certain question? Geistesgeschichte identifies which writers are the "great dead philosophers" and thereby creates a canon of reputable predecessors which clarifies the historiographer's own point of departure. This trend can easily lead to an honorific or doxographic account of the history of philosophy, or for that matter the history of any science. In the end the doxographic account merely legitimises the historiographer's own point of view without any contribution to a better understanding of past philosophy or science and should be allowed to "whither away". The last genre is an intellectual history which combines the first three genres. Rational reconstructions help the historiographer to come to grips with his own problems, historial reconstructions remind the investigator that these problems are historical products and Geistesgeschichte provides the self-justification or confidence which most scientists need. Intellectual history describes what intellectuals were up to during a certain period of time and how they interacted with their society.

In the end Rorty admits that we all need canons of reputable predecessors, mountain peaks of achievement to draw our intellectual maps by and selfjustificatory Geistesgeschichte to legitimate our own academic point of departure. But we need less honorific doxographies and many more different and competing canons, Geistesgeschichten and intellectual histories that inculcate a sense of historical contingency and self-awareness in the historiographer and scientists in general.

Some attention should be given to the writing of the history of a specific scientific discipline because this article ultimately aims at addressing the problems confronting the historiographer of Old Testament studies.

Since Kant a scientific discipline has been seen as a self-subsisting system of thought in its own right and with its own history. The historiographer of a 
scientific discipline will try to recover the intentions of past scientists, to reconstruct mutually adhered to conventions and to restore the contexts within which everything took place ${ }^{18}$. Therefore the history of a discipline should concentrate on the rational coherence of past thought forms and paradigms, the influence of major institutional arrangements and social conditions as well as the reconstruction of the historical context. The history of a discipline should never degenerate into being a mere chronicle of who discovered what and when! Neither should it be an apologetic account of who went "wrong", who first exposed the "error" and who established "right" answers according to the historiographer's point of view.

Koyré's method of conceptual analysis has had an important influence on discipline history. According to this analysis, the extreme variability in "scientific" ideas or terminology used over a period of time and the accompanying recurrent ambiguities come to the historiographer's attention. This approach pointed out that scientific ideas or theories are not merely logical results emanating from scientific investigation, but that they evolve within a specific intellectual, institutional, economic and social context ${ }^{19}$.

If the pitfalls of discipline history are taken to heart, they should deter even eminent scholars from preparing histories of their field of special interest in which they impose their categories of thought and paradigms on the past ${ }^{20}$.

It is important to reconsider the historiography of the study of the Old Testament by relating it to recent trends in the historiography of science and the history of scientific disciplines.

After ten years of extensive research Ludwig Diestel published his Geschichte des Alten Testamentes in der christlichen Kirche in 1869. It is clear from the title of the book that little attention was given to Jewish or other non-Christian interpretations of the Old Testament. He not only acknowledges this "wesentlichen Mangel", but also confesses a lack of attention to non-German contributions to the understanding of the Old Testament. Despite these lacunae, Diestel's work was the result of years of thorough research and it was well received by Old Testament colleagues such as $\mathrm{H}$ Ewald, who commented: "das Werk füllt... eine wahre Lücke aus..."21. Diestel's Geschichte remains an important and indispensable reference work despite its obvious inductivist approach to historiography.

T K Cheyne wrote his Founders of Old Testament criticism in 1893 as "a series of pictures of eminent Old Testament critics from the critical movement". It was important for him "to notice how the intellectual phases and material surroundings of a writer have affected his criticism" and "to remove some current mistakes and misconceptions" about a critical approach to the study of the Old 
Testament. His specific brand of inductivist historiography causes him to come to the conclusion that a critical approach is "natural and inevitable" within the context of the founders of Old Testament criticism ${ }^{22}$. An intriguing aspect of Cheyne's book is the scant attention paid to Wellhausen as one of the critical "founders", by only referring to him in passing as "a faithful disciple of Ewald, whose principles he does but apply more consistently, and therefore with different results"23. This lack of attention to Wellhausen may be understood in the light of a remark made by Cheyne in an article on Ewald: "we will not even criticize him (Wellhausen) - it would be a tragic waste of time - till we understand him" 24 . Cheyne's book still impresses one with the extent of his personal acquaintance with many of the critical "founders", but it remains an apologetic type of history to legitimise his own point of view. This is made quite clear by the concluding remark of his book: "my chief grounds for advocating such a criticism is that it appears to me to be becoming more and more necessary for the maintenance of true evangelical religion"25.

History of Old Testament criticism was written by Archibald Duff in 1910 and he set out to tell "the story of the critical or literary handling of the Old Testament throughout the ages". According to his "preface" the only condition laid upon him was that his tale had to be "the true one". In his first chapter "Of our ideal, and our plan" he reflects on the students of his age who "seek to find just the facts and then to systematise these, calling the result Science" and he concludes "to get all of the facts, we must trace the stream of phenomena right up to the first fountainhead"26. That is the reason why he starts off from the year $900 \mathrm{BC}$ by asking how Hebrew man thought about his literature and he criticises Diestel for his neglect of the Jewish interpretation of the Old Testament. His "chief question and interest" with his History was: "Does the history of Old Testament criticism exhibit always the character of God as just like Jesus?"27

E M Gray published his Old Testament criticism. Its rise and progress. From the second century to the end of the eighteenth in 1923 . He tries his utmost to present an unbiased account of the development of Old Testament criticism because "the history of this early criticism has been variously represented, according to the standpoint of the relater", but he still considers it possible to conduct an "independent investigation" 28 . The reason for beginning from the second century is that "the so-called higher criticism is, after all, but the modern expression... of a similar attitude... making its first appearance in the days of the early Fathers of the Church"29. Gray's intention to return to Germany to deal with the history of the nineteenth century was made impossible by the first World War.

Looking back at the first attempts at writing the history of Old Testament studies, one is struck by its correlation with historiographical trends in general. Diestel, Cheyne, Duff and Gray adhered to the nineteenth and early twentieth century inductivist or "whig" historiography of science by presupposing continuing 
progress in Old Testament studies based on naive realism.

One of the most important contributions made to the historiography of Old Testament studies was the Geschichte der historisch-kritischen Erforschung des Alten Testaments von der Reformation bis zur Gegenwart, first written in 1956 by Hans-Joachim Kraus. This extensive study begins in the sixteenth century with the contributions of the Reformers and the biggest part of the book deals with the period from the Aufklärung in the eighteenth century to the beginning of the first World War. The central problem discussed in the book as a whole is:

\begin{abstract}
Was ist aus dem reformatorischen Bekenntnis sola scriptura unter dem Anwachsen der historischen Kritik geworden? Schiesslich haben die Reformatoren dochmit ihrer totalen Zuwendung zur Heiligen Schrift den ganzen Prozess heraufgeführt der sich in der historischkritischen Forschung abwickelt ${ }^{30}$.
\end{abstract}

Kraus is not satisfied with the "geistesgeschichtlichen und theologiegeschichtlichen Zusammenhange" of Diestel's "Geschichte" and he considers Duff and Gray's work to be too succinct.

It serves little purpose to repeat Kraus's often criticised lack of attention to non-German or non-Lutheran scholarship and his bifocal interpretation of Old Testament studies which concentrates predominantly on the Reformation's understanding of Scripture and the development of historical criticism. It is interesting that the second edition published in 1969 took some of the criticisms to heart and made a few changes. The second edition deleted the last part of the title, von der Reformation bis zur Gegenwart and some attention was then paid to earlier and nonGerman understanding of the Old Testament. A third edition was published in 1982 with the addition of three new paragraphs on aspects of recent scholarship that tickled Kraus' fancy but which did not necessarily reflect Old Testament scholarship as a whole. Kraus broke new ground with his Geistesgeschichte of German historical criticism but succumbed to the honorific and doxographic temptations of a disciplinary history that primarily sets out to legitimise one's own point of departure.

Ronald E Clements wrote the first edition of $A$ century of Old Testament study in 1976 and describes it as a sketch of the ways in which the Old Testament has been interpreted since Wellhausen, with the emphasis upon questions of methodology. Each chapter deals with the significant contributions made in the main sections of the Old Testament canon. Although he only indulges in a short introduction, a few important points are made which deserve more attention. He is of the opinion that "the rise of critical Old Testament scholarship was the product of a number of contemporary philosophical presuppositions". Clements considers the rise of a critical approach primarily due to the assumption "that a foundation of historical fact can be attained by use of the appropriate methods of study, and that this 
historical foundation... can shed light upon the true nature of biblical faith" 31 . In the last chapter of his revised edition, published in 1983, he concludes that the development of Old Testament scholarship "has been a constant process of defining aims and fashioning the methods and tools appropriate to them"32.

The detailed Bibelautorität und Geist der Moderne. Die Bedeutung des Bibelverständnisses für die geistesgeschichtliche und politische Entwicklung in England von der Reformation bis zur Aufklärung was completed by Henning Graf Reventlow in 1980. This study points out that modern biblical criticism took its early rise in England and is acutely aware of the interaction between secular and theological concerns. During this period political thinkers scrutinised the Bible for its models because church and state politics were closely allied. According to Graf Reventlow the interaction between humanism and reformed theology led to the subordination of biblical authority and this brings us to the underlying reason for a German Alttestamentler to write a book on past English theological thought. It seems as if the author tries to identify the reasons for the decline in the authority of the Bible and counteracts the view that the historical-critical method is the continuation of Lutheranism. Graf Reventlow is of the opinion that the neglect of a basic tenet of the Reformation of justification through faith alone and not through works is the main reason for the decline in the authority of the Bible. This was due to the understanding of Christianity as a system of moral action that rendered revealed religion superfluous ${ }^{33}$. Graf Reventlow admirably illustrated the correlation between secular and theological concerns and thereby utilised non-theological aspects that assume the broadly contextual conditioning of the study of the Bible.

In 1982 two histories of biblical studies in Canada and the United States were published in the Biblical scholarship in North America series. The church historian, J S Moir, wrote $A$ history of Biblical studies in Canada: $A$ sense of proportion by interpreting Canadian biblical studies within its social, cultural and ecclesiastical setting. He suggests that the nineteenth century's uncritical fusion of religion with national life and the conservative German influence of $F$ Delitzsch from Leipzig, where most Canadian post-graduate students in theology went, set a conservative trend that survived for more than a century. After outlining the contributions of prominent scholars, he discusses a few controversies and he concludes by mentioning the emphasis on language training and conservative interpretation as the distinctive characteristics of Canadian biblical scholarship ${ }^{34}$. E W Saunders, a New Testament scholar, was responsible for Searching the Scriptures. $A$ history of the SBL 1880-1980. He calls it a "biographical study of an organisation", an "anecdotal history" and a "white-washed sepulchre", which in his dedication is "Respectfully and Affectionately Submitted" to the SBL. One should therefore not expect a rigorous historical critical study of the SBL, but an indication of how the Society would like to view itself. Two topics were discussed from the very beginning 
up to the present: the dominant German influence in biblical scholarship and the controversy surrounding the "sacredness" of the biblical text. Within one century the SBL developed from a mere forum where new scholarship could be discussed to a research center that stimulates, sponsors and criticises scholarly activity 35 . Moir, and to a lesser extent Saunders, focused on the socio-historical context of biblical studies and represent aspects of an "external" trend in the historiography of science.

John Rogerson deals with two basic questions in Old Testament criticism in the nineteenth century: England and Germany (1984). These questions concentrate on how the critical method arose in Germany in the nineteenth century and how its reception in England was influenced by the theological and philosophical climate of the time. The reason for this investigation is to establish the causes for Protestant Germany being the "home" for the critical method and "the place of its most creative use"36. This book steers clear of the temptation to evaluate scholars in terms of a personally cherished ideal, but it does consider the difference in religious and philosophical atmosphere in England and Germany as a very important element of the context within which scholars worked. There is no trace of inductivist historiography when Rogerson discusses the role of "chance" as part of the haphazard progress of Old Testament scholarship. According to Rogerson the two main reasons for the difference between English and German Old Testament scholarship were the diverging theological centers, incarnation and justification by faith, and the strong empirical basis in English theology and philosophy which is best at evaluation and not at discovery. Rogerson made an exciting contribution by avoiding the usual pitfalls of self-justification and has provided a challenging explanation of the nineteenth century development of the historical critical method.

\section{FUTURE OF THE HISTORIOGRAPHY OF OLD TESTAMENT SCHOLARSHIP}

At the end of the Jerusalem IOSOT congress, held in August of 1986, R Rendtorff anticipated the end of the road for historical criticism. Although it might still be a little premature to write an obituary, a significant number of historical-critical hypotheses such as the Pentateuch sources theory and the amphictiony have lost its general acceptance. It seems as if Kuhn is correct that the criticism of a predominant paradigm is accompanied by soul-searching and the contemplation of alternative paradigms. In such a context the self-awareness created by a disciplinary history of the Old Testament studies can obviate self-criticism and the more general acceptance of historical contingency.

Historical criticism in particular, and perhaps Old Testament scholarship in general, can be rejuvenated by rigorous historical investigation of its scientific cultures and research activities in the past. Current historical critical presup- 
positions and assumptions underlying the interpretation of the Old Testament can best be understood in terms of the theoretical framework and the broader historical context from which modern scholarship evolved and developed. Arguments concerning existing and possible new paradigms of Old Testament interpretation must heed the source material provided by the historiography of Old Testament studies.

The historiographer of Old Testament scholarship need not only be a tolerated cuckoo, a legitimating canonizer of reputable antecessors or a cartographer of past "progress". More attention to the history of Old Testament studies within different contexts and periods of time may provide valuable sounding-boards that facilitate more accountable interpretation of the Old Testament text.

\section{NOTES:}

1 Magne Saeboe stressed in his paper on "the History of OT Studies", delivered at the XII IOSOT Congress in Jerusalem (August 1986): "What is most needed now is a comprehensive presentation which is based on modern scholarship...". The paper emphasised the ecumenical co-operation in such a venture but almost no reference was made to recent trends in the historiography of science.

2 H Guerlac, Essays and papers in the history of modern science, Baltimore 1977, 54-55.

3 P T Durbin (ed), A guide to the culture of science, technology and medicine, New York 1984, 7.

4 J Losee, A historical introduction to the philosophy of science, Oxford 1985, 120.

5 B Croce, Theory and history of historiography, London 1921, 264-307.

6 E Mach, The science of mechanics. A critical and historical exposition of its principles, Chicago 1893, 450.

7 P Duhem. Le système du monde. Histoire des doctrines cosmologiques de Platon à Copernic, vol 6, Paris 1913, 21-30.

8 G Sarton, Six wings: Men of science in the renaissance, Baltimore 1957, vii.

$9 \quad$ A Koyré, Etudes Galiléennes, vol 3, Paris 1939.

10 H Guerlac, Some historical assumptions of the history of science, in: A C Crombie (ed) Scientific change, London 1963, 797-812.

11 K R Popper, The logic of scientific discovery, London 1972, 50-53.

12 B Barnes, Scientific knowledge and sociological theory; 1974. D Bloor, Knowledge and social imagery, London 1976. 
13 H Butterfield, The history of historiography and the history of science, in: Mélanges Alexandre Koyré, vol 2, Paris 1964, 37-68.

14 J Agassi, Towards an historiography of science, s'Gravenhage 1963, 29.

15 D M Knight, "The history of science in Britain: A personal view", Zeitschrift für allgemeine Wissenschaftstheorie 15(1984), 346-348.

$16 \quad \mathrm{~K}$ van Berkel, "Wetenschapsgeschiedenis en wetenschapsfilosofie: enige misvattingen", Kennis en Metode 8(1984), 83-89.

17 R Rorty, The historiography of philosophy: four genres, in: R Rorty, J B Schneewind and Q Skinner (eds), Philosophy in history. Essays on the historiography of philosophy, Cambridge 1984, 49-75.

18 L Graham, W Lepenies and P Weingart (eds), Functions and uses of disciplinary histories, Dordrecht 1983.

19 Durbin, ibid, 22.

20 T S Kuhn, "The relations between history and the history of science", Daedalus 100 (1971), 273-300.

21 S Wagner, Nachwort, in: L Diestel, Geschichte des Alten Testamentes in der christlichen Kirche, Leipzig 1981, 823.

22 T K Cheyne, Founders of Old Testament Criticism, London 1893, vi.

23 Cheyne, ibid, 197.

24 T K Cheyne, "The life and works of Heinrich Ewald", The Expositor 4 (1886), 368.

25 Cheyne, ibid, 372.

26 A Duff, History of Old Testament criticism, London 1910, 1.

27 Duff, ibid, 7.

28 E M Gray, Old Testament criticism. Its rise and progress. From the second century to the end of the eighteenth, New York 1923, 9.

29 Grey, ibid, 8.

30 H-J Kraus, Geschichte der historisch-kritischen Erforschung des Alten Testaments von der Reformation bis zur Gegenwart, Neukirchen-Vluyn 1956, 4.

31 R E Clements, $A$ century of Old Testament study (rev ed), Guildford (1983), 3.

32 Clements, ibid, 179.

33 H Graf Reventlow, Bibelautorität und Geist der Moderne, Göttingen 1980, 1-6. 
34 J S Moir, A history of biblical studies in Canada, Chico 1981, 8 \& 109.

35 E W Saunders, Searching the Scriptures, Chico 1982, xii \& 58.

$36 \mathrm{~J} \mathrm{~W}$ Rogerson, Old Testament criticism in the nineteenth century, London 1984 , ix. 